\title{
Religion, politics, and ritual. Remarks on Geertz and Bloch*
}

Most people would allow - recalling Remembrance Day parades and royal coronations - that even in modern societies religious rituals may sometimes serve political purposes. Anthropologists today would want to go much further than this, however, and argue that politics and social life everywhere have - to put it at its mildest - a fundamental ritual and symbolic aspect. Thus there has in recent years been a revival of interest in the study of ritual both among anthropologists and among scholars sympathetic to anthropology. ${ }^{1}$ In addition, there has been a more ethnographically based revival of interest, from a variety of theoretical perspectives, in studying the political aspects of ritual. ${ }^{2}$ In this essay I wish to consider ritual - taken in the more or less conventional sense as formal, significant, symbolically intended and complex action $^{3}-$ and to ask whether there can be a global theory of how it works.

I shall begin by contrasting two eminent theorists of ritual, Clifford Geertz (in particular the Geertz of Negara [1982]) and Maurice Bloch. I shall try to draw out how far they differ and what they share. I will then attempt to illustrate how one might progress further, using some material from Nepal, the area of my own ethnographic competence, such as it is.

It is worth emphasising at the beginning that I choose to concentrate on these two authors because I admire them, both as ethnographers and as theorists. I believe that both of them repay detailed attention. ${ }^{4}$ It is because their work is valuable and lasting

\footnotetext{
* I would like to thank J.-C. Galey, A. Kuper, D. P. Martinez, J. Pfaff-Czarnecka, D. Quigley, and C. Toren, as well as participants in discussion at Zürich University, for helpful comments on earlier versions of this paper. A German translation, by Joanna Pfaff-Czarnecka, has appeared in C. Caduff and J. Pfaff-Czarnecka (eds.) Rituale Heute (1999, Berlin: Reimer Verlag).

1 See, for example, Bell (1992), Humphrey and Laidlaw (1994), Boyer (1994).

2 In addition to the works discussed in this essay, I am thinking of Kertzer (1988), Harrison (1995), Boholm (ed.) (1996), Peabody (1997); for a useful survey, see Kelly and Kaplan (1990).

3 See Tambiah (1985a). This means not extending 'ritual' to cover any formalised action, such as shaking hands, but rather restricting it to sets of actions that are recognised by the actors themselves as set apart from mundane activities.

4 As a small example of the fruitfulness of Bloch's theory, one could cite the way he uses it to throw new light on Paul's rejection of the circumcision ritual for early Christians. This was dictated, he shows, less by Paul's universalism, as is conventionally believed, than by his millenarianism (Bloch 1992: 91-4).
} 
that I think it worth attempting to criticise it. Both have sought to deal with the political and social implications of ritual and to do so by means of detailed ethnographic and historical work. Against Geertz, I shall argue that his interpretivist stance undermines the attempt to draw general lessons from his single case. Against Bloch, I shall argue that his monistic theory cannot work as it stands and needs to be supplemented by a theory of kinds of ritual, in other words, a typology. With Bloch, I shall be arguing for a historically grounded and generalising theory, however ambitious and premature that may seem.

\section{Clifford Geertz}

Of my two emblematic authors, Geertz is certainly the better known and has already been the subject of many interesting critiques. ${ }^{5}$ One reason to focus on Geertz is the sheer weight of his influence. This influence can be measured both by the prominence to which his students have risen and by the pervasiveness of his ideas (which in turn can be measured, if you want quantitative precision rather than interpretative understanding, by that quintessentially modern invention, the citation index). I focus on Negara because it combines Geertz's mature understanding of culture with a fulllength ethnographic monograph on the role of ritual in politics - indeed on ritual as politics.

Geertz, it is hardly necessary to say, stands for the idea of interpretation or hermeneutics. The task of the anthropologist is not to count lineages or measure fields in an attempt to come up with causal hypotheses. Nor is it to pretend to 'get inside people's heads' or to seek for historical processes or to impose supposedly scientific order. It is to interpret cultures, understood as systems of symbols. Anthropologists are specialists in other people's meanings. There are better and worse interpretations, but interpretations can never be final. There can be no natural-scientific, right-for-alltime answers. In Geertz's own words (1973: 29), 'Cultural analysis is intrinsically incomplete ... Anthropology, or at least interpretive anthropology, is a science whose progress is marked less by a perfection of consensus than by a refinement of debate. What gets better is the precision with which we vex each other.'

When Geertz started out, in Harvard, under the influence of Talcott Parsons, anthropology was viewed as one part of an inter-disciplinary team (Kuper 1994: 540; 1999). Biology, psychology, and sociology were equally necessary to understand human behaviour; anthropology was there to deal with 'culture'. By the time of The interpretation of cultures (1973), Geertz had left this notion behind. Anthropology as interpretive quest could interpret any field of human action. Just because it was 'symbolic' in its method did not mean that it was not equally appropriate to apply it to subject matter that is conventionally defined as the opposite of 'symbolic': e.g. violence, economics, urbanisation, or agriculture (Geertz 1973: 30), an idea that has been extremely influential in American cultural anthropology.

Geertz came to the study of the Balinese politics only after a long apprenticeship in Indonesian anthropology. In Negara he is concerned both to advance his theory of how the traditional Balinese state worked and simultaneously to argue for a more

5 See Asad (1983), Shankman (1984), Munson (1986), Kuper (1999), to cite only a few. 
symbolic or expressive view of politics everywhere. It is to Geertz's great credit that before beginning to consider the details of royal ritual, he devotes two substantial chapters to considering kinship and political alliance, including material on local government, the 'feudal' links between villagers and lords, and the politics of irrigation and trade. He gives a detailed description of the social organisation of Balinese villages, focusing on the relationship between the ordinary villagers and their overlords, as the context in which the state operated. What he shows is that the regulation of everyday life was handled at the village level: 'Perhaps the bulk ... of Balinese government, in the strict sense of the authoritative regulation of social life, was carried out by the hamlet, leaving the state free to dramatise power rather than to administer it' (Geertz 1982: 49). Villagers, in fact, had just two duties to their lords: to pay taxes and contribute labour or resources for rituals or fighting. Ties of organisation were crosscutting and fragmented, so that any concentration of power was necessarily fragile and short-lived.

The Balinese courts may not have controlled much politically in the villages they dominated, but they were the unambiguous cultural centres of the country. The continual elaborate ceremony

was an argument, made over and over again in the insistent vocabulary of ritual, that worldly status has a cosmic base, that hierarchy is the governing principle of the universe, and that the arrangements of human life are but approximations, more close or less, to those of the divine (ibid. 102).

Thus

the stupendous cremations, tooth filings, temple dedications, pilgrimages, and blood sacrifices, mobilising hundreds and even thousands of people and great quantities of wealth, were not means to political ends; they were the ends themselves, they were what the state was for ... [M] ass ritual was not a device to shore up the state, but rather the state, even in its final gasp, was a device for the enactment of mass ritual. Power served pomp, not pomp power (ibid. 13).

It was, in short, a 'theatre state'.

Despite the powerful and compelling rhetoric, there is unfortunately an ambiguity in Geertz's argument, which he never completely faces up to. Are the Balinese typical or are they an extreme case? Is politics always and everywhere equally about symbols? Or is it more symbolic in Bali than in, say, modern Switzerland?

Nonetheless, there is an important lesson, which Geertz drives home. Modern political science, obsessed with economic models of voting patterns and other scientistic paraphernalia, has completely missed the extent to which ritual of various sorts is still a central concern, both of political leaders today, and of the people who vote them into power. That Ronald Reagan agreed with Geertz can perhaps be deduced from the comment he is supposed to have made shortly after he was elected President: his aides weren't leaving him enough time to be President. The idea that politics are essentially about ritual and symbolism - despite the difficulty we have in perceiving our own actions as symbolic and against the view that symbolism and ritual matter only to the backward or the simple-minded - has been eloquently taken up and illustrated with numerous historical and anthropological examples by David Kertzer (1988). Kertzer goes beyond Geertz in two ways: first, in the genuinely global reach of 
his comparisons and, second, because he emphasises the fact that ritual is equally important both to those who dominate and to those who resist domination. ${ }^{6}$

\section{Maurice Bloch}

Maurice Bloch is less well known than Clifford Geertz and certainly does not occupy the powerful position within British or European anthropology that Geertz does in the USA. Nonetheless, he is a highly interesting writer and in some ways is typical of British social anthropology, for all that he has an unusual interest in Marxism. His fieldwork has been almost entirely on the island of Madagascar, beginning with his $\mathrm{PhD}$ on kinship and ancestor rituals (Bloch 1971). He subsequently wrote an introductory book, Marxism and anthropology (1983), and there is a collection of his influential essays, Ritual, history and power (1989). What I wish to concentrate on here is the monograph From blessing to violence. History and ideology in the circumcision ritual of the Merina of Madagascar (1986) and his short work Prey into bunter. The politics of religious experience (1992).

Bloch has long been known as a Marxist, or at least as an anthropologist sympathetic to Marxism. One might think that this would lead him to be diametrically opposed to Geertz. Where Geertz concentrates on the interpretation of symbolic meanings, Bloch would surely cut through these, seeing them as mere mystification, and focus instead on structures of power. But in fact Bloch is far from being a crude Marxist. He is as interested as other anthropologists, perhaps more so, in the analysis of ritual and symbolism. The difference is that he has always sought to show how these work to maintain structures of power and inequality. His Marxist inclinations are also apparent in the position he took up in his celebrated but controversial essay, 'The past and the present in the present' (Bloch 1977): he argued that there is, on the one hand, ritual communication which both obscures and legitimates hierarchy and, on the other hand, everyday practical communication which gets closer to how things 'really are'.

In From blessing to violence Bloch examines, rather like Geertz in Negara, the rituals of the Malagasy royal state and the way in which they legitimated social and political hierarchy. Bloch provides rather less information on the social organisation that underlay the state than Geertz, but he gives more detail on the ritual itself and in particular on the way that it was transformed between approximately 1780 and 1970 . The ritual of circumcision started as a private, small-scale and irregular affair which involved only the immediate relatives of the boys going through it. Then, with the expansion of the Merina kingdom in the middle of the nineteenth century, the circumcision of royal princes became a seven-yearly ritual involving the whole country, and became more and more elaborate. The army was given a prominent role in order to celebrate Merina conquests. A clear symbolic link was made between the violence of the ritual and the domination of neighbouring peoples. At the same time

6 Kertzer also links his argument to developments in cognitive psychology (1988: 179). In a later passage he situates himself with respect to both Geertz and Bloch: against Geertz, he points out that 'the best that elites can hope to do is shore up a predominant symbolic construction of how society should work. They can never eliminate all loose ends ... nor all vestiges of alternative symbol systems' (1988: 176-7). Kertzer agrees with Bloch that there are universal processes of human cognition grounded in similar material conditions, but he rejects the claim that there are two distinct kinds of cognition and communication, the ritual and the everyday (Bloch 1977, Kertzer 1988: 203 n. 9). 
the circumcision of commoner boys was linked to the royal circumcision ritual; being circumcised became simultaneously an act of allegiance to the throne. With the adoption of Christianity in 1869, the ritual was driven underground and reverted to being a small-scale familial affair. After independence from France in 1960 the ritual started to be performed more openly and began to be seen as an anti-elite and antiChristian rite.

The important point here is that through all these changes, modifications, and reversals, there was a central core of ritual acts and meanings which did not change. Contrary to what a simplistic functionalist approach might suggest, different social needs did not generate different rituals; the same ritual satisfied very different needs at different periods, and even within the same period. Bloch's explanation of this is intended simultaneously to be an answer to the question how ritual can serve to legitimate domination, not just in the eyes of the rulers, but in the eyes of the ruled as well.

The first thing Bloch has to do is reject certain crude reductionisms in the interpretation of ritual. Ritual should not be seen simply as doing something social (the functionalist position). Nor should it be seen either as expressing something (the symbolicist position) or as saying something (the intellectualist position). Rituals, he remarks, lie 'somewhere between an action and a statement' (1986: 10); thus they cannot be reduced either to the one or to the other. Rituals certainly do 'do', 'express', and 'say' things, but they do so ambiguously, and this ambiguity is of the essence. The ambiguity permits different and opposed levels of understanding among those who share allegiance to the same ritual.

It is precisely because rituals do not simply say things that they acquire their power to persuade and legitimate. There is a gap between everyday communication and ritual communication but it is not, and cannot be, an insuperable gap (which Bloch takes to be Geertz's position in Negara). There has to be some connection between what is implied in ritual, on the one hand, and everyday life, on the other, for the ritual to work as a legitimating device. Bloch concludes (1986: 191) that 'the ritual is a vague, weakly propositional, construction of timelessness built on an antithesis that will do for any domination ... It offers [the Merina] order in exchange for submission'. The very complexity of the symbolism, and the fact that the ritual offers them incorporation within a descent group, explains why women are as enthusiastic participants as anyone else, even though the ritual they participate in legitimates their secondary status. ${ }^{7}$

Bloch's second book, Prey into hunter, based on the Morgan Lectures given in 1987, is explicitly an attempt to take the argument further by means of considering global examples. Bloch certainly deserves praise for attempting to do this, in a way that Geertz, consistently, one might say, with his interpretive and anti-generalizing view of anthropology, has never done. ${ }^{8}$ In Prey into hunter, Bloch argues that all religious rituals have a common core; they all share a similar symbolic structure of 'rebounding violence' (a term introduced here for the first time).

7 For a similar discussion, see Kertzer (1988: 176).

8 Geertz has not argued against comparison as such. He could hardly do so, having himself written a distinguished comparative study of Islam in Morocco and Indonesia (Geertz 1968). However, the thrust of his interpretivism is certainly against attempts to construct global and/or systematic comparisons. 
As in van Gennep's and Victor Turner's theories, rituals for Bloch consist of three stages. In the initial stage they are about the aggressive domination of the forces of life (or 'vitality' as Bloch calls it). During this stage violence is directed at individuals or at animals identified with them. In the next stage of the ritual the principal actors are separated from the forces of life and acquire a transcendent quality. In the final stage, with this transcendence incorporated, the actors return to life empowered and revivified.

Bloch recognises that this common structure can be used in a variety of ways and in his conclusion he attempts a typology of such uses:

The symbolism of rebounding violence offers at least three alternative avenues of legitimate practice and in addition any mixture of the three: (1) the assertion of reproduction; (2) the legitimation of expansionism, which itself takes one of two forms: (a) it may be internally directed, in which case it legitimates social hierarchy, or (b) it may be externally directed and become an encouragement to aggression against neighbours; (3) the abandonment of earthly existence ... Which particular alternative dominates and informs action is largely, though not exclusively, determined by people's evaluation of their politico-economic circumstances ... (Bloch 1992: 98)

Clearly these are intended to be 'ideal types' in the Weberian sense, though Bloch avoids the latter term. He illustrates type (1) with the religious symbolism of the Orokaiva of Papua New Guinea. In fact Bloch begins his analysis with the Orokaiva because the initiation of Orokaiva children - first chased out of the village like pigs and later returning in triumph as hunters and distributors of pig meat - illustrates the 'prey into hunter' theme particularly well and gives him the title of his book. Bloch sees cattle sacrifice among the Dinka of the Sudan, even though performed for what I call instrumental reasons (as explained below), in much the same way. Likewise, despite some symbolic difficulties, spirit mediumship among the Buid of the Philippines is also interpreted as being about 'the assertion of reproduction'. Type (2a) - internally directed expansionism - is used to explain the subordination of women and is illustrated with Maria Phylactou's (1989) material on marriage by capture in Ladakh. Type (2b) - the legitimation of expansionism directed externally - is advanced with the examples of Hindu India and Japan. The traditional Hindu idea of kingship, Bloch claims, 'implies exactly that image of the consuming conqueror' (p. 49) which is also found in the other rituals he analyses. In the Japanese case he tries to connect the symbolic violence of Shinto ritual (itself not always obvious) with the militarism of the 1930s. Bloch's own material on the Merina of Madagascar, as outlined in From blessing to violence, also clearly falls into this type, as well as into type (2a). Bloch's type (3) stands for millenarianism and is illustrated both by material from Madagascar and by the history of early Christianity. In a final chapter he looks at the Ma'Betisek aborigines of Malaysia who, when their normal healing rituals fail, then invoke the commonality of human beings and plant and animal life. This is to 'conjure up a truly radical rejection of rebounding violence in ritual' (ibid. 104). In extreme situations, then, Bloch recognises that the symbolism of violence can be abandoned.

\section{Geertz versus Bloch}

Before moving to a critique of Bloch, it is worth considering what both Geertz and Bloch share, and where they differ. Both have been drawn to look at the historical 
background of the place where they did fieldwork (or in Geertz's case, one of the places). Both have analysed the symbolism and ritual of the premodern monarchical state, and at what happened in the encounter with colonialism. Surprisingly, Geertz, the interpretivist, includes more detail on trade, irrigation, land-holding and villagelevel organisation than Bloch, the Marxist, does. ${ }^{9}$ Perhaps equally surprisingly, Bloch provides far more ethnographic detail and much closer symbolic analysis of his chosen ritual. Geertz discusses the main themes and examines the main indigenous concepts, but he declines to get involved in the microscopic details of ritual. (He might have done so, despite the lack of elaborate court ritual today, in the way Bloch did, namely, by focusing on local-level equivalents that continue today.)

Whereas Geertz insists that the ritual has a clear message - that the king is close to the gods - Bloch argues that the message can never be entirely clear: its fuzziness is of the essence. For Bloch, it is precisely because the message is not clear that the ritual has the power to legitimate social and political hierarchy. The medium is the message and the medium is somewhat opaque. Ritual is an act that asserts and has meaning, but which cannot be argued with. Both Geertz and Bloch are working in an earlier tradition of anthropology which emphasises the conservative power of ritual; neither pays much attention to the question, so important in contemporary American cultural anthropology, of how far rituals may be used to contest established structures of power.

Both Geertz and Bloch have been criticised for not taking the effects of colonialism sufficiently into account. Thus Berg (1986) has suggested that in the eighteenth and nineteenth centuries in Madagascar the relationship of ritual and practical knowledge was very close: at this time 'the ritual expressed contractually the social hierarchy based on land and controlled by the descent group'. It was only later, with the decline in the importance of landholding as a source of power, that the gap Bloch claims to be universal, between the transcendent world of ritual and the real world of social relations, opened up. In a somewhat similar way several critiques of Geertz suggest that what he has described is the Balinese state at the period when the Dutch had removed much of its ability to coerce and wage war and when, therefore, there was a greater emphasis on timeless ritual. ${ }^{10}$

Bloch, unlike Geertz, looks at 'his' ritual in history, i.e. how it has changed over time, although while doing so he uses a disconcerting analogy from physics (1986: 183) which is probably best ignored. However, the stress on history and process really only applies to the Bloch of From blessing to violence and not to the Bloch of Prey into bunter. Finally, Geertz does not maintain that there is a core of symbolic meaning that can be found globally; he merely implies that the role of ritual in politics has been ignored on a global scale. Bloch, on the other hand, attempts in an extremely ambitious way to test the approach he worked out for Madagascar in a variety of worldwide contexts.

9 Berg (1986) notes that 'what is lacking is historical information about changes in landownership, changes in the rights and obligations of initiates with regard to land and other forms of wealth, variation in the performance of circumcision rituals among outgroups such as slaves or hinterland demes far from power, and change in relation of urban to rural elites at the close of the nineteenth century.'

10 See Lansing (1991), Schulte Nordholdt (1993), Kuper (1999). For a similar analysis of the famous Swazi Ncwala ritual, showing how an appreciation of the colonial context is essential, see Lincoln (1987). 


\section{Three kinds of religion and ritual. A critique of Bloch}

What are we to make of Bloch's theory? It is evident that it works better in some cases than others. It is no coincidence that Bloch begins with the Orokaiva and their frightening initiation rituals in which boys are hunted like pigs in order to become men. But as the book proceeds the strain in the argument increases. When he is discussing Shintoism he has to work very hard, and indulge in considerable ingenuity, to make the theory fit a religion in which there is no place for animal sacrifice. Thus, for example, he argues that Buddhism in Japan provides the first stage of rebounding violence, aimed at the self, in that it prepares the Japanese for death. Shintoism, on the other hand, mobilises young people and symbols of violence for this worldly purposes. He recognises that the theme of violence is much less obvious than in the Orokaiva case. He coins the term 'piscivorous' (on the model of 'carnivorous'), since the Japanese are not much given to meat-eating, and he argues:

\footnotetext{
The piscivorous aspect of Shintoism links up with the strength-giving aspect of carnivorous activities and is a general, implicit, but powerful theme of Japanese life ... [I]n modern Japan the eating of raw fish and meat also takes on the form of a kind of secular aggressive ritual in certain types of restaurants or bars mainly patronised by men. There the theme of violent consumption is expanded to the extent that the fish needs to be shown to be alive immediately before it is eaten. Sometimes slices of it are eaten while it is still wriggling on the dish and sometimes the whole fish is eaten alive. It is difficult not to see this type of activity as a celebration of the conquest of other forms of life, which brings us back to the Orokaiva concluding feasts (ibid. 60).
}

It would be easy to criticise such argument for ignoring the interpretations of the participants themselves, and for using the theory to explain the material, rather than the material to test the theory. But such problems are encountered by any attempt at a global theory, and I want to present a rather different critique.

In my opinion, no such theory of ritual can work unless it recognises that the whole category of 'religion' is a question-begging Western, or Judaeo-Christianderived, term. Because of the exclusivist assumptions of Christianity there have been centuries of misunderstandings of Asian religions. The category of religion needs to be deconstructed; it should be replaced by a hierarchy of (at least) three types of religion. First comes soteriology or salvation religion. Second is social or communal religion, the kind about which Durkheim was concerned to theorise and for which his theory works well. Third, there is instrumental religion, the attempt to make specific things happen within the world. It will be noted that this approach does not define religion in terms of belief, but in terms of what is done; and it distinguishes between the different purposes for which different kinds of religious actions are done. ${ }^{11}$

Rituals may usually be ascribed predominantly to one or other type. Those concerned primarily with salvation from all the ills of this world are soteriological, those which express the solidarity of the group or incorporate individuals within it are social, and those which attempt to cure illness, ensure a successful business enterprise or the passing of an exam may be considered instrumental. Naturally enough there may well be many rituals which combine aspects of more than one type of ritual, or which are transformed over time from being predominantly of one type to predomi-

11 I have used this typology in my monograph on Newar Buddhism (Gellner 1992), and also explored it in a separate article (Gellner 1988). 
nantly one of the others. I will illustrate such a movement when I describe a textreading ritual below.

Not every religion possesses each type of ritual. There are 'tribal' religions which lack a soteriology. If I understand the material on the Kham Magar, a small group of remote mountain villagers in Nepal famous for their shamanism, there is in their ritual and social life a relative de-emphasis on both soteriology and social religion. The instrumental rituals of their shamans dominate the religious field (Oppitz 1986; de Sales 1991).

In many situations in Asia, which westerners have found so hard to understand, there are different religious systems serving different religious purposes. According to Tambiah's classic analysis of north-east Thailand (1970: 338), there were four related religious systems: Buddhism provided for the salvation and collective village meritmaking rituals; the 'Sukhwan' ritual specialists known as paabm (the Thai for 'Brahman') took care of rites of passage; local guardian spirits, worshipped through mediums, protected the village fields and their fertility; and, finally, malevolent spirits causing illness were dealt with by diviners and exorcists. Each of the four systems had separate specialists, separate rituals and its own characteristic ritual language. Each was defined by its position in the overall system. Soteriology was unambiguously the realm of Buddhism. Different aspects of social religion were dealt with by each of the first three systems. Instrumental religion is the sphere of the fourth. In Gombrich's account of Sri Lanka (1971) there is a simpler opposition between Buddhism and the gods of Hinduism, but a similar analysis could be attempted there too (cf. Ames 1966).

The main point is that Theravada Buddhist monks, until the modern period, never aspired to provide for all the laity's needs. Their respected status derived precisely from the fact that they were supposed to have nothing to do with mere worldly matters. They were concerned with salvation and, provided that Buddhism's overall ideological hegemony was not threatened, they did not mind what cults their laypeople resorted to for purely worldly ends. Gombrich sums this up by saying that 'Buddhism in real life is accretive' (1971: 41; original emphasis). In other words, it must always coexist with some other religious system or systems which provide for the worldly needs of its adherents. This coexistence is not necessarily syncretic or improper. ${ }^{12}$

In practice, of course, many monks have always been involved in astrology, had mistresses, or ran businesses. But the significant point is that this was in spite of, not a consequence of, their religious role. The highest prestige went to those monks who carried out their role to the full. There is some evidence that forest-dwelling monks did not always have higher status than those involved in book-learning and servicing the laity (Gombrich 1988). But it seems likely that in the past as today (Carrithers 1983) the forest monks were the most attractive for the laity as recipients of their donations, if only because they were the most inaccessible.

What of the category 'world religions'? The very notion has been rightly attacked as a nonsense, a collection of disparate phenomena classed together in order to satisfy the needs of religious studies classes where like must be compared with like (Fitzgerald 1990). Thus, the religions of Asia, such as Hinduism, Buddhism and Shintoism are forced into the Procrustean bed of Judaeo-Christian categories. They must each have

12 For more on the question of Buddhism and syncretism, and for a comparison of the relationship between Buddhism and other religious systems in Nepal and Japan, see Gellner (1997). 
their ethics, doctrines, life-cycle rituals, festivals, prophets and scriptures. In the terminology I have introduced, Buddhism started as a soteriology and in most of the countries it has spread to it has remained overwhelming so, although in Mahayana countries it has adapted to provide many instrumental rituals alongside its soteriological ones. In Nepal, among the Newars, as described below, it has adapted further than elsewhere: it provides for all the needs of social religion as well. Hinduism, by contrast, is essentially a social religion which has numerous alternative soteriologies within it, so that many people have doubted whether it should be considered a single religion at all. Shintoism, on the other hand, is primarily a social and instrumental religion, with virtually no soteriology. Soteriology has, even post-Meiji, been left to Buddhism.

Despite these differences, there is one characteristic that all the world religious soteriologies have in common: a radical rejection or reordering of the world as such, based either on a jealous and all-demanding God, or on the necessity of taking a path away from all worldly things. It is not, as is sometimes claimed, that non-literate religions have no concept of the transcendent: this is an idea that Bloch criticises convincingly. But in 'tribal' religions it is a transcendent that can be accessed only occasionally and contextually.

Soteriologies, at least at their outset, are based on the rejection of conventional religious thinking. In some cases old symbolism is retained but transformed, e.g. Christ's self-sacrifice as the Lamb of God: here, a sacrificial religion is given a new meaning. In Bloch's theory this can be seen as a transformation of his rebounding violence. But in other cases, not even the symbolism is retained. It is hard to see pacifist rituals in terms of 'rebounding violence': hence the strained way in which Bloch interprets Buddhist pilgrimage in Japan as the first part of 'rebounding violence', namely as 'attacks on vitality' (Bloch 1992: 55). The rejection of animal sacrifice is central to Buddhism. The examples from Nepal discussed below go some way to illustrate this.

Furthermore, not only is Bloch's theory as applied to soteriological rituals problematic, it is even more difficult to see it applying to instrumental rituals. Sometimes the means by which instrumental rituals are understood to be effective, to bring about the desired change in the world, is in line with Bloch's ideas about sacrifice. At other times changes in the world are believed to be effected by strictly soteriological means (I shall give an example presently). At still other times a more oldfashioned Frazerian explanation, in terms of ritual as bastard science, is more appropriate.

What this shows is that Bloch's theory works best for social religion. His theory is really about how complex symbolism helps to construct social order. This suggests that, for all his residual Marxism, Bloch is equally, if not all the more, a Durkheimian: it is the construction of order that receives all the emphasis and little or no attention is paid to conflicting or 'subaltern' viewpoints.

\section{Three Newar rituals}

My three examples come from the Kathmandu Valley, Nepal, where I have myself done fieldwork, and can speak with some confidence about their interpretation (Gellner 1992; Gellner and Quigley 1995). The three rituals are the guru mandala puja, 
the annual festival of Dasain, and the ritual of text-reading in the Kwa Bahah monastic temple complex known to foreigners as 'The Golden Temple'.

The Kathmandu Valley is a fertile bowl at 1000 metres in the foothills of the Himalayas. Before 1769 it housed three small competing kingdoms (Kathmandu, Lalitpur and Bhaktapur) each based on a small city of about 60,000 people with its associated rural hinterland. The royal rituals of these cities, and the manner in which they fought each other endlessly, were not wholly dissimilar from Geertz's nineteenth-century Bali, or indeed Bloch's early nineteenth-century Madagascar. In 1769, Prithvi Narayan Shah of Gorkha, the ancestor of the present king of Nepal, conquered the Kathmandu Valley, which paved the way for the creation of the present-day state of Nepal.

In this way the people of the Kathmandu Valley, the Newars, became an encapsulated minority (between 5 and 6 percent) of the new country. Many Newars emigrated from the valley to become the traders and shopkeepers of the new polity. Those who remained behind to a greater or lesser extent preserved their preunification language, social organisation, religious traditions and rituals. Some Newars are Buddhist, others Hindu. The prime means of differentiation is by priest. Those Newars whose domestic priest is a Vajracharya count as Buddhist; those who call a Brahman are Hindu. The Vajracharyas have been dubbed 'Buddhist Brahmans': they are indeed, like Brahmans, a married, hereditary priesthood. Together with a slightly lower sub-section of the same caste, called Sakya, they control and preserve the temple complexes, called vihara or bahab (monastery) in Newari, which are the main sites for Buddhist worship. This coexistence of Buddhism and Hinduism is highly unusual in South Asia, but was once far more common. The great French Sanskritist, Sylvain Lévi, came to Nepal in 1898, and wrote a history of the country in three volumes (1905), because he felt that Nepal was 'India in the making', i.e. the coexistence of Buddhism and Hinduism in the Kathmandu Valley was typical of the situation in India a thousand years ago, before the Muslim invasions. The kind of Buddhism practised by the Newars is highly ritualised (Gellner 1992). There are no large monastic institutions as in Tibet or South-East Asia, so the level of scholarship is obviously much lower. But, all the same, just like Tibetan Buddhism, and in some respects more so, it is a direct lineal descendant of the Mahayana and Vajrayana Buddhism practised in north India and what is now Bangladesh seven to eight hundred years ago.

\section{The guru mandala puja}

The first ritual to be considered is the guru mandala puja. It is the most basic item of Newar Buddhist liturgy, i.e. it is the first complete ritual learned by a novice priest and in the past many lay-people knew how to perform it too. All complex rituals, requiring the presence of a Vajracharya priest, begin and end with the guru mandala. It acts as a kind of frame for the whole ritual. It may also be performed on its own, as part of one's personal daily ritual. On its own it takes about five minutes if known by heart, but it took me 36 pages when I wanted to publish a blow-by-blow account of every utterance and ritual act that make it up (Gellner 1991a). Briefly described, it consists of the following four stages:

(1) Building up the mandala (i.e. sacred enclosure) of Mt. Meru (the cosmic mountain 
at the centre of the world) by making small offerings to each element of the mandala;

(2) Offering the mandala to Vajrasattva, the guru, who is a symbol of the Tantric Buddhist absolute;

(3) Various Mahayana Buddhist undertakings (e.g. to become a Buddha to save all beings and a confession of sins);

(4) An offering to lower spirits to prevent obstacles.

When (as is usually the case) the guru mandala is used as the frame of a larger ritual, this final part is held over till the end.

This framing function means that the guru mandala is fundamental to all Newar Buddhist rituals. The only significant occasion when it is absent is in the daily worship of the main Buddha statue in monastic temple complexes, and even there many parts of it are often incorporated (Gellner 1991b; Sharkey 1994). Mothers perform the guru mandala on behalf of their five- or six-month-old babies at the First Rice-feeding. Married couples perform it together onto a single shared mandala during the wedding ceremony. In terms of my three types of religion, the guru mandala, taken on its own, is clearly soteriological in intent; but the way it is used varies from the soteriological (e.g. as part of a pious Buddhist practitioner's daily devotions) to the social (e.g. when part of a larger life-cycle ritual).

There is a considerable range of understandings of this ritual. The least sophisticated parishioners or patrons of Vajracharya priests do not even know its name. They simply perform the rite under the instructions of their priest. As far as they are concerned, both understanding it and ensuring its success are the priest's work and duty; they neither want nor need to know its details. For the priest's part, he sees no need to explain what he is doing to his parishioners, especially if they are lower caste, unless they particularly want to know.

Others know the name of the ritual, and know that the mandala is offered to Vajrasattva, but cannot perform it themselves without the guidance of a priest. Still others, including priests themselves and many pious lay people, perform it daily as part of their regular devotions and do so by heart and fluently.

The ritual has remained essentially unchanged since the twelth century. It may be several hundred years older than that. But in any case it is at least that old. We know this because the ritual appears, virtually as it is today, and in exactly the context in which it would be used today, in the Kriya Samuccaya by Jagaddarpana Acarya, which dates from the twelfth century. Today minor parts of the ritual are performed in slightly variant orders by different priests. This is due to the fact that there are different ritual traditions within each city, and in Lalitpur (and perhaps elsewhere too) within the city as well. Despite such variations, it is, in its essentials, the same ritual everywhere.

The explanation for this standardisation and fixity must lie in the specialised training of Vajracharya priests, and in the fact that it is a ritual they perform so often that it becomes second nature to them. No Vajracharya who carries on the priesthood can fail to know it by heart. At the same time it is a purely Buddhist liturgy, with the recitations chanted incomprehensibly in Sanskrit. It is therefore of no concern to outsiders and is opaque to many, perhaps most, of the Buddhist laity. Consequently there has been no incentive to elaborate it, or control it, on the part of the (Hindu) powers that be. It has neither grown nor shrunk in the years in which it is possible to trace its history. 


\section{Dasain}

Dasain is a very different kind of ritual. It is the biggest public holiday in Nepal. It is the one festival for which Nepalese everywhere try to be at home. Everyone is supposed to receive a blessing in the form of a vermilion spot on the forehead (tika) on the tenth day of the month, the climax of the festival, from their household head, from the elders of their lineage, and ideally from the King himself. Even Muslims participate in this, stopping short only at receiving a red spot of vermilion, substituting colourless cooking oil (Gaborieau 1996). The main divinity worshipped is the goddess Durga, and the principal means by which she is worshipped is the sacrifice of buffaloes and goats. Pumpkins, cucumbers and other gourds are also often substituted. The close connection between the worship of Durga and the successful maintenance of power may be illustrated by the fact that every police station in Nepal has a small Durga shrine outside it. ${ }^{13}$

In the Malla period the main ritual act seems to have been the parade of swords, empowered by the goddess. This gave it its Newar name, payah or khadgajatra, literally 'the sword festival'. In this form it seems to go back at least to the thirteenth century (Petech 1984: 95). The parade of swords is still practised today: several highcaste Srestha lineages still go in procession with ancient swords draped in the barley shoots which are planted on the first day of the month in their lineage's secret goddess shrine. These swords are frequently used to 'sacrifice' a pumpkin: all the initiated men of the lineage line up and slash it as they pass. Possession by the goddess is indicated when the man or youth holding the sword shakes and trembles.

With the advent of the Shah dynasty in the eighteenth century, the procession with swords from the royal palace, in which the Malla kings had themselves participated (G. Vajracharya 1976: 187), receded in importance. A further change introduced was that the barley seeds were planted in Nuwakot, outside the Kathmandu Valley, from where its conquest was planned, and then brought on the seventh day (Phulpati) to the royal palace, a clear recapitulation of the conquest of the Valley from the north-west. But in most other respects the traditions of the Malla rulers of the three cities of the Kathmandu Valley were maintained by the new dynasty; still today the rituals of Dasain unfold in parallel in the three old royal palaces of Kathmandu, Lalitpur and Bhaktapur, supported by the Guthi Samsthan, the government office that oversees religious activities funded by (mainly royal) land grants of the past.

The Rana Prime Ministers who ruled Nepal from 1854 to 1951 never actually replaced the kings of Nepal, who remained as symbolic figureheads, rather like the Emperor in pre-Meiji Japan. The Ranas did systematise the reappointment of government servants, called pajani, by holding it annually during the Dasain festivities (Pfaff-Czarnecka 1993: 277). Government servants had to attend in full ceremonial dress, never knowing whether they would be reappointed for the next year. If they were not, they had to walk away without the turban which the ruler gave them as a sign of their position, a very public humiliation. It seems also to have been the Ranas who added the military parades and the worshipping of regimental colours (ibid. 274-5). Perhaps Jang Bahadur was influenced by what he had seen in England. ${ }^{14}$

13 For an unrivalled collection of material on Dasain, see Krauskopff and Lecomte-Tilouine (eds.) (1996). See also Levy (1990 s.v. Mohani), Pfaff-Czarnecka (1993, forthcoming). For an equivalent in India, see Schnepel (1996).

14 On Jang Bahadur's trip to England and France, see Whelpton (1983). Of course, the worship of weapons was an integral part of Dasain even before this. 
Today civil servants have more secure tenure and no longer have to parade at Dasain, though before 1990 there were many occasions, including Dasain, when gazetted officers were expected to demonstrate their support of the regime and the throne. Military parades continue alongside the more traditional animal sacrifices and masked dances. The king still gives tika, in order of precedence to his priests, family, leading figures of the government and to the general public (Lecomte-Tilouine and Shrestha 1996). At the same time as these large-scale public events, there is also a small reduplication at the level of the family. Household heads give tika within the house just as the king and headman do so within their respective political domains.

Dasain is, then, the prime calendrical festival of Nepal. It symbolises the harvest, fertility, royal power and the power of the patrilineage, including the dominance of males over females (Bennett 1982). As such, it does what Bloch claims of the circumcision ritual for the Merina in the nineteenth century: it legitimates and symbolises worldly order. Like the circumcision ritual, it is highly susceptible to the accretion of new elements added by new dynasties or new political regimes, as well as to being publicly contested. Thus, since 1990 in particular, it has begun to be contested by the activists of many 'ex-tribal' ethnic groups who now wish to define themselves as non-Hindu. ${ }^{15}$ There is also an older tradition of Tibetan Buddhist practitioners carrying out rituals to compensate for the sin of so many sacrificed animals. Even before 1990, as Toffin (1996: 89) shows, there seem to have been disputes between different priests over the right to control specific rituals.

Does the ritual of Dasain achieve its effects through the 'construction of timelessness', as Bloch claims for the Merina circumcision ritual? It is arguable that in the Hindu world it is above all the high Hindu god, Shiva or Pashupati, or perhaps Vishnu, who stands for this, whereas the symbolic force of the goddess - her ability to stand for fertility, power and control - comes from her location within the world. In other words, the more timeless a divinity is, the less useful for this-worldly purposes. It is the relatively less transcendent nature of the goddess that makes her appropriate for the acquisition of worldly power.

Despite this split within the Hindu divine universe, between male otherworldliness symbolised by the high gods Shiva and Vishnu, and the more worldly power of the goddess which is the symbolic centre of the rituals of Dasain, in other respects it must be allowed that the messages of Dasain fit rather well with Bloch's analysis in Prey into bunter. Fertility, regeneration, royal power and conquest, national unity and the domination of lineage elders (and of men over women) are all tied together and guaranteed by animal sacrifice. It seems like a perfect illustration of 'rebounding violence'.

\section{Text-reading in Kwa Bahah}

My third example is a ritual called pa thyakegu (or path yakegu), 'having the text read', which is frequently held in the monastic temple complex of Kwa Bahah, Lalitpur (Gellner 1996). The text that is read is called 'The perfection of wisdom in eight thousand lines' and may be as much as 1900 years old (though this copy is more like 700 years old). There is more to the ritual, however, than just having the text read. The

15 Pfaff-Czarnecka (forthcoming) shows that in some local cases this was happening already before 1990. On the politicisation of culture in Nepal generally since 1990, see Gellner, Pfaff-Czarnecka, and Whelpton (eds.) (1997). 
local people believe that reading this copy of the text, in the manner specified by tradition, guarantees the fulfilment of one's wishes. Ten Vajracharya priests each take a share of the text, perform the guru mandala ritual, and then read through, either silently or nearly so, the Sanskrit of the text, simultaneously with all the others. It is a common practice to vow to have the text read if one is in danger, either from disease, from travel, at work, or in any other way. The local people of Lalitpur believe that the goddess, the Perfection of Wisdom, has really become present in this text and that she answers the petitions of her worshippers. Many of them also have the text read when not in dire need, e.g. for weddings or initiations.

The historical evidence, so far as I have been able to reconstruct it, suggests that the ritual as it is today dates from the eighteenth century, or possibly only from the mid-nineteenth century. Today it is read on about two days out of three. Present-day officiants remember having to introduce a rule that it could only be read twice a day.

This ritual is clearly instrumental in nature, for all that it is cast in an unimpeachably Mahayana Buddhist soteriological idiom. ${ }^{16}$ Of 184 Sakya and Vajracharya households living in the vicinity of Kwa Bahah, 114 (62 percent) had had the text read at least once for one reason or another in the last ten years. The most common reason was illness, cited explicitly by just over 30 percent. It is probable that many of the 28 percent who simply said that they wished to have the text read also had it done for reasons of illness. Some 5 percent mentioned fears to do with jobs, 3.5 percent longdistance travel, another 3.5 percent misfortune or inauspiciousness at home, 2.6 percent rites to do with death. Nearly 17 percent mentioned an auspicious occasion at home, such as a wedding.

\section{Recapitulation}

Of these three Newar rituals, the first is clearly soteriological, although it is used as a basic building block of Newar Buddhist liturgy and is therefore found in social and instrumental ritual contexts as well. The second ritual, Dasain, as a calendrical festival, is primarily social. The third ritual is predominantly instrumental, though the form in which it is cast is soteriological.

\section{Conclusion}

It should be clear from these three examples, described very schematically, that there are many different types of ritual. Bloch's central argument is that (1) in a 'weakly propositional' manner (1986: 191) rituals construct order - a timeless, unchanging world - and legitimate dominance; and (2) they do this through the symbolism, and to differing degrees the enactment, of 'rebounding violence' (1992). In From prey into bunter Bloch tries to show that this applies to a wide range of rituals. Inevitably, he is forced to recognise the great heterogeneity of rituals and he proposes a typology of the

16 I suspect that the increasing popularity of the ritual in recent years may have something to do with the decline of other traditional instrumental rituals performed by Vajracharyas (e.g. the worship of the Pancaraksa goddesses, and the navagraba puja). 
uses of ritual, which I have quoted above (p. 140). In my opinion this does not go nearly far enough and a more radical typology of ritual itself is required, with each type of ritual likely to have different characteristic symbolic structures.

Of the three types of ritual that I have proposed, Bloch's theory clearly works best for social rituals. He has in fact been criticised for leaving out of his account of the Merina circumcision ritual any consideration of the sampy cult, which was primarily instrumental in orientation (Berg 1986); it is also noticeable that Christianity, which might be taken to be soteriological, plays only a small part in his analysis. I have illustrated social rituals with the Dasain festival, and I have suggested that Bloch's account should really be seen as Durkheimian in intent, with its emphasis on ritual and symbolism producing order.

My second criticism of Bloch is that there is too much stress on the ritual itself and not enough on the institutions which enable it to be preserved over long periods. Surprisingly for a supposed Marxist, social history is introduced only as background. It is here that we can learn from Geertz, supposedly the more hermeneuticist author. For he, quite rightly, thinks that without knowing about the details of control over irrigation, the place and importance of the royal centre cannot be understood either. What is needed is the emphasis on history, ritual and the impact of colonialism that both authors seek, combined with Bloch's interest in the sociological implications and micro-analysis of ritual detail, and Geertz's wide-angled awareness of context. Geertz, on the other hand, has been criticised for a bias in his application of such contextual considerations: for restricting his symbolic analysis to the elite level and implying that the ordinary people are concerned with technical rationality alone (Tambiah 1985b: 336; Valeri 1991: 135-6). I have already noted that Geertz in particular is also open to the charge of not going far enough in including the colonial context in his analysis.

Thus I side with Bloch against Geertz in seeking a universal theory, but I reject Bloch's monistic assumption that all ritual must fit a single framework: at least three fundamentally different kinds of ritual and religious orientation must be recognised. All three types of ritual share the features of redundancy, stereotypy and formalisation that have been identified by many authors (e.g. Tambiah 1985a); but different purposes lead them to be inflected symbolically in very different ways. Bloch's assumption that 'rebounding violence' is a structural feature of all rituals is inappropriate for soteriological and liturgical rituals like the guru mandala puja and it is equally inappropriate for an instrumental ritual like the text reading I have described. Although both 'posit timelessness', neither is violent in any way, unless Bloch is going to construe the purity rules that have to be observed to carry them out as some kind of violence. By contrast, his framework seems to work very well for the major calendrical festival of Dasain. Even here, however, I wonder whether it is wise to exclude the possibility of annual festivals based on some other kind of symbolic nexus.

What both the authors I have discussed agree upon - as well as many others I have not mentioned - is that if we want to understand why people perform rituals and what it means when they do so, we have to take into account their political aspect. And furthermore both Geertz and Bloch exemplify a wholly necessary and admirable rapprochement between anthropology and history. To Bloch's aspiration for a systematic theory I have added the rider that we need a typology of religion and ritual to make that plausible. The idea that there is a single 'thing' called religion or a single kind of ritual is an outmoded and too frequently unexamined part of the 
Judaeo-Christian inheritance of the human sciences - an idea we should abandon forthwith.

David N. Gellner

Department of Human Sciences

Brunel University

Uxbridge UB8 $3 P H$

U.K.

\section{References}

Ames, M. M. 1966. 'Ritual prestations and the structure of the Sinhalese pantheon', in M. Nash (ed.), Anthropological studies in Theravada Buddhism. New Haven: Yale University Press.

Asad, T. 1983. 'Anthropological conceptions of religion. Reflections on Geertz', Man 18: 237-59.

Bell, C. 1992. Ritual theory, ritual practice. Oxford and New York: Oxford University Press.

Bennett, L. 1982. Dangerous wives and sacred sisters. Social and symbolic roles of high-caste women in Nepal. New York: Columbia University Press.

Berg, G. A. 1986. Review of Bloch 1986, Current Anthropology 27: 353.

Bloch, M. 1971. Placing the dead. Tombs, ancestral villages and kinship organisation in Madagascar. London: Seminar.

1977. 'The past and the present in the present', Man 12: 278-92; reprinted in Bloch 1989.

1983. Marxism and anthropology. The history of a relationship. Oxford: Clarendon.

1986. From blessing to violence. History and ideology in the circumcision ritual of the Merina of Madagascar. Cambridge: Cambridge University Press.

1989. Ritual, history and power. Selected papers in anthropology. London: Athlone.

1992. Prey into hunter. The politics of religious experience. Cambridge: Cambridge University Press.

Boholm, A. (ed.). 1996. Political ritual. Göteborg: Institute for Advanced Studies in Social Anthropology.

Boyer, P. 1994. The naturalness of religious ideas. A cognitive theory of religion. Berkeley: University of California Press.

Carrithers, M. 1983. The forest monks of Sri Lanka. An anthropological and historical study. New Delhi: Oxford University Press.

Fitzgerald, T. 1990. 'Hinduism and the 'world religion' fallacy', Religion 20: 101-18.

Gaborieau, M. 1996. 'Le grand dilemme des Musulmans. Comment participer au pouvoir sans le sacraliser?', in G. Krauskopff and M. Lecomte-Tilouine (eds.), Célébrer le Pouvoir. Dasai, une fête royale au Népal. Paris: CNRS.

Geertz, C. 1968. Islam Observed. New Haven: Yale University Press.

1973. The interpretation of cultures. Selected essays. New York: Basic Books.

1982. Negara. The theatre state in nineteenth-century Bali. Princeton: Princeton University Press.

Gellner, D. N. 1988. 'Priesthood and possession. Newar religion in the light of some Weberian concepts', Pacific Viewpoint 29(2): 119-43.

1991a. 'Ritualized devotion, altruism and meditation. The offering of the guru mandala in Newar Buddhism', Indo-Iranian Journal 34: 161-97.

1991b. 'A Newar Buddhist liturgy. Sravakayanist ritual in Kwa Bahah, Lalitpur, Nepal', Journal of the International Association of Buddhist Studies 14: 236-52.

1992. Monk, housebolder and Tantric priest. Newar Buddhism and its hierarchy of ritual. Cambridge: Cambridge University Press.

1996. 'A text and its uses in Kwa Baha, Lalitpur', in S. Lienhard (ed.). Change and continuity. Studies in the Nepalese culture of the Kathmandu Valley. Alessandria: Edizioni dell'Orso/CESMEO.

1997. 'For syncretism. The position of Buddhism in Nepal and Japan compared', Social Anthropology 5: 275-89.

Gellner, D. N. and D. Quigley (eds.). 1995. Contested hierarchies. A collaborative ethnography of caste 
among the Newars of the Kathmandu Valley, Nepal. Oxford: Clarendon Press (paperback, with corrections: Delhi: OUP, 1999).

Gellner, D. N., J. Pfaff-Czarnecka and J. Whelpton (eds.). 1997. Nationalism and ethnicity in a Hindu Kingdom. The politics of culture in contemporary Nepal. Amsterdam: Harwood.

Gombrich, R. F. 1971. Precept and practice. Traditional Buddhism in the rural highlands of Ceylon. Oxford: Clarendon Press.

1988. Theravada Buddhism. A social history from ancient Benares to modern Colombo. London and New York: Routledge.

Harrison, S. 1995. 'Four types of symbolic conflict', Journal of the Royal Anthropological Institute 1: 255-72.

Humphrey, C. and J. Laidlaw. 1994. The archetypal actions of ritual. A theory of ritual illustrated by the Jain rite of worship. Oxford: Clarendon Press.

Kelly, J. D. and M. Kaplan. 1990. 'History, structure and ritual', Annual Review of Anthropology 19: 119-50.

Kertzer, D. 1988. Ritual, politics and power. New Haven: Yale University Press.

Krauskopff, G. and M. Lecomte-Tilouine (eds.). 1996. Célébrer le pouvoir. Dasai, une fête royale au Népal. Paris: CNRS.

Kuper, A. 1994. 'Culture, identity and the project of a cosmopolitan anthropology', Man 29: 537-54.

1999. 'Clifford Geertz. Culture as religion, and as grand opera', in A. Kuper, Culture. The anthropologists' account. Cambridge, Mass.: Harvard University Press.

Lansing, J. S. 1991. Priests and programmers. Technologies of power in the engineered landscape of Bali. Princeton: Princeton University Press.

Lecomte-Tilouine, M. and B. K. Shrestha. 1996. 'Les rituels royaux de Dasai à Katmandou. Notes preliminaires', in Krauskopff and Lecomte-Tilouine (eds.).

Lévi, S. 1905. Le Népal. Etude historique d'un royaume hindou, 3 vols. Paris: Leroux. (Reissued 1986, Kathmandu and Paris: Raj de Condappa, Le Toît du Monde and Editions Errance.)

Levy, R. I., with K. R. Rājopādhyāya. 1990. Mesocosm. Hinduism and the organisation of a traditional Newar city in Nepal. Berkeley: University of California Press.

Lincoln, B. 1987. 'Ritual, rebellion, resistance. Once more the Swazi Ncwala', Man 22: 132-56.

Munson, H. 1986. 'Geertz on religion. The theory and the practice', Religion 16: 19-32.

Oppitz, M. 1986. 'Die Trommel und das Buch. Eine kleine und die grosse Tradition', in B. Kölver and S. Lienhard (eds.), Formen kulturellen Wandels und andere Beiträge zur Erforschung des Himalaya. St Augustin: VGH Wissenschaftsverlag.

Peabody, N. 1997. 'Inchoate in Kota? Contesting authority through a north Indian pageant-play', American Ethnologist 24: 559-84.

Petech, L. 1984 [1958]. Medieval History of Nepal, second edition. Rome: ISMEO.

Pfaff-Czarnecka, J. 1993. 'The Nepalese Durga Puja festival, or displaying political supremacy on ritual occasions', in C. Ramble and M. Brauen (eds.), Antbropology of Tibet and the Himalaya. Zürich: Ethnological Museum of the University of Zürich.

forthcoming. 'A battle of meanings. Commemorating goddess Durga's victory over demon Mahisa as a political act', Kailash.

Phylactou, M. 1989. 'Household organisation and marriage in Ladakh'. Unpublished PhD thesis, University of London.

de Sales, A. 1991. Je suis né de vos jeux de Tambours. La religion chamanique des Magar du nord. Nanterre: Société d'Ethnologie.

Schnepel, B. 1996. 'The Hindu king's authority reconsidered. Durga-Puja and Dasara in a south Orissan jungle kingdom' in Boholm (ed.).

Schulte Nordholt, H. 1993. 'Leadership and the limits of political control. A Balinese "response" to Clifford Geertz', Social Anthropology 1: 291-307.

Shankman, P. 1984. 'The thick and the thin. On the interpretative program of Clifford Geertz', Current Anthropology 25: 261-79.

Sharkey, G. C. J. 1994. 'Daily ritual in Newar Buddhist shrines'. Unpublished D.Phil. thesis, Oxford University. 
Tambiah, S. J. 1970. Buddhism and the spirit cults in north-east Thailand. Cambridge: Cambridge University Press.

1985a. 'A performative approach to ritual', in S. J. Tambiah, Culture, thought and social action. An anthropological perspective. Cambridge, Mass.: Harvard University Press.

1985b. 'A reformulation of Geertz's conception of the theater state', in S. J. Tambiah, Culture, thought and social action. An anthropological perspective. Cambridge, Mass.: Harvard University Press.

Toffin, G. 1996. 'Histoire et anthropologie d'un culte royal népalais. Le Mvahni (Durga Puja) dans l'ancien palais royal de Patan', in G. Krauskopff and M. Lecomte-Tilouine (eds.).

Vajracharya, Gautam Vajra 1976. Hanumān Dhokā Rājdarbār (in Nepali). Kathmandu: CNAS.

Valeri, V. 1991. 'Afterword', in Lansing 1991.

Whelpton, J. 1983. Jang Bahadur in Europe. The first Nepalese mission to the west. Kathmandu: Sahayogi. 